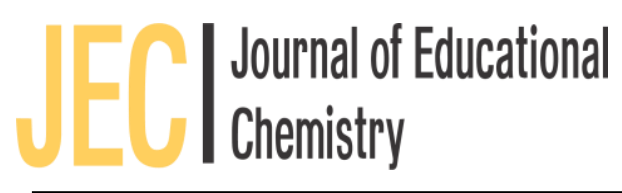

Journal of Educational Chemistry (2 (1), 2020, 1-8)

Website: http://www.journal.walisongo.ac.id/index.php/jec

ISSN 2715-3029 (p) 2685-4880 (e)

DOI: 10.21580/jec.2020.2.1.5512

\title{
Pengembangan Perangkat Pembelajaran pada Mata Kuliah Kimia Dasar Berdasarkan Kurikulum KKNI
}

\author{
Anggi Desviana Siregar \\ Institut Agama Islam Negeri Kerinci \\ E-mail: anggidesviana56@gmail.com
}

\begin{abstract}
A learning tool is one of the important factors in influencing learning achievement, especially in higher education. Through the improvement of the learning tools, will facilitate students in understanding the material. This study aims to develop learning tools in the form of Lesson Plan (RPS) and the Design of students' assignment (RTM) based on the Indonesian National Qualification Framework (KKNI) curriculum. This development was conducted in basic chemistry subjects for Chemical Engineering majors at Institut Teknologi Medan (ITM). This study used a 4-D model development research design by Thiagarajan, however in this study, it only included the 3 steps namely define, design, and develop. Two expert validators were involved in this study, namely development experts and material experts. The validation result showed that the average value of RPS and RTM is 3.75 (very feasible criteria). In other words, the developed learning tools that are in line with the Indonesian National Qualification Framework (KKNI) curriculum.
\end{abstract}

Keywords: design of students' assignment, KKNI curriculum, learning tools, lesson plan 


\begin{abstract}
Abstrak
Perangkat pembelajaran merupakan salah satu faktor penting dalam mempengaruhi keberhasilan pembelajaran terutama diperguruan tinggi. Dengan meningkatkan kualitas perangkat pembelajaran, maka dapat memudahkan mahasiswa dalam memahami materi termasuk materi pembelajaran kimia. Penelitian ini bertujuan untuk mengembangkan perangkat pembelajaran berupa Rencana Pembelajaran Semester (RPS) dan Rancangan Tugas Mahasiswa (RTM) sesuai kurikulum kerangka kualifikasi nasional indonesia (KKNI). Pengembangan ini dilakukan pada mata kuliah kimia dasar dijurusan Teknik kimia Institut Teknologi Medan (ITM). Penelitian ini menggunakan rancangan penelitian pengembangan model 4-D oleh Thiangarajan, namun pada penelitian ini hanya sampai pada 3 tahap yaitu tahap pendefinisian, tahap perancangan, dan tahap pengembangan. Validator yang terlibat pada penelitian ini adalah validator ahli pengembangan dan ahli materi. Hasil validasi perangkat pembelajaran diperoleh nilai rata-rata kedua perangkat adalah 3,75 (kriteria sangat layak). Hal ini berarti perangkat pembelajaran yang dibuat sudah sesuai dengan kerangka kualifikasi nasional Indonesia.
\end{abstract}

Kata Kunci: kurikulum KKNI, perangkat pembelajaran, rancangan tugas mahasiswa, rencana pembelajaran semester

\title{
Pendahuluan
}

Pemerintah Indonesia telah melakukan banyak upaya dalam rangka meningkatkan mutu kualitas pendidikan. Upaya yang telah dilakukan pemerintah salah satunya yaitu pembaharuan kurikulum di lembaga pendidikan, termasuk kurikulum di perguruan tinggi (Solikhah, 2015). Perubahan kurikulum merupakan proses yang wajar terjadi sejalan dengan berbagai perkembangan ilmu pengetahuan dan teknologi (IPTEK), kebutuhan dalam masyarakat, kemajuan zaman, dan kebijakan baru dari pemerintah (Kemendikbud, 2014).

Kurikulum yang sedang dikembangkan di beberapa perguruan tinggi Indonesia adalah Kerangka Kualifikasi Nasional Indonesia (KKNI). KKNI merupakan penjenjangan kualifikasi 2

Copyright (C) 2020 JEC | ISSN 2715-3029 (p) 2685-4880 (e) Volume 2, Nomor 1, 2020 kompetensi yang dapat menyandingkan, menyetarakan, dan mengintegrasikan antara bidang pendidikan dan bidang pelatihan kerja sesuai dengan struktur pekerjaan di berbagai sektor.

Berdasarkan Pepres No.8 Tahun 2012 dinyatakan bahwa implementasi KKNI tersebut mempertimbangkan tujuan pendidikan dalam bentuk penciri ilmu pengetahuan dan keterampilan, keahlian berkarya, sikap berperilaku dalam berkarya dan cara berkehidupan bermasyarakat sebagai persyaratan minimal yang harus dicapai peserta didik dalam penyelesaian suatu program studi. Secara konseptual, jenjang kualifikasi dalam KKNI disusun oleh empat parameter, yaitu: (1) keterampilan kerja, (2) cakupan keilmuan 
(pengetahuan), (3) metode dan tingkat kemampuan mengaplikasikan keilmuan, dan (4) kemampuan manajerial. Internalisasi dan akumulasi keempat parameter yang harus dicapai melalui proses pendidikan yang terstruktur atau melalui pengalaman kerja sebagai capaian pembelajatan (learning outcome). Penetapan capaian pembelajaran (learning outcome) di perguruan tinggi mengandung 4 unsur deskripsi KKNI yaitu aspek kemampuan umum, kompetensi di bidang kerja, di bidang pengetahuan, dan kompetensi manajerial. (Perpres RI No. 8, 2012).

Institut Teknologi Medan (ITM) merupakan salah satu perguruan tinggi yang melaksanakan kurikulum berbasiskan KKNI. Kurikulum KKNI diterapkan disemua jurusan termasuk jurusan Teknik kimia. Berdasarkan hasil observasi dan wawancara dengan salah satu dosen kimia di ITM, maka diketahui beberapa dosen masih mempelajari dan mulai menyusun perangkat pembelajaran berdasarkan kurikulum KKNI pada setiap mata kuliah yang diajarkan, salah satu mata kuliahnya adalah kimia dasar. Menurut Prausnitz proses pembelajaran pada di Teknik Kimia juga perlu diberi perubahan atau pengembangan hal ini dipengaruhi perubahan dunia, hal ini dirangsang oleh perkembangan seperti teknologi, politik, lembaga-lembaga sosial, yaitu dengan perubahan dalam cara orang berpikir, etika dan keyakinan oleh sikap dan harapan (Prausnitz, 2011). Oleh karena itu, proses pembelajaran di jurusan teknik harus mampu menghadapi tantangan besar dalam rangka memberikan mahasiswa tidak sekedar pengetahuan, tetapi juga memiliki relevansi terhadap keterampilan, serta aspek-aspek pendidikan yang relevan untuk sifat yang lebih fleksibel, interdisipliner (Iborra, 2013).

Penelitian ini bertujuan untuk mengembangkan perangkat pembelajaran berupa Rencana Pembelajaran Semester (RPS) dan Rancangan Tugas Mahasiswa (RTM) pada mata kuliah kimia dasar dijurusan Teknik kimia. Dasar hukum dalam penyusunan rencana pembelajaran yang dirancang ini mengacu kepada Permenristekdikti Nomor 44 Tahun 2015. Pada pasal 12 disebutkan, rencana pembelajaran semester ditetapkan dan dikembangkan oleh dosen secara mandiri atau bersama dalam kelompok keahlian suatu bidang ilmu pengetahuan dan/atau teknologi dalam program studi. Standar perangkat pembelajaran yang disusun ini harus terkait dalam perspektif KKNI, setiap program studi diharuskan memperjelas profil lulusan yang diharapkan melalui kegiatan pelacakan studi, studi kelayakan dan analisis kebutuhan di masyarakat. Profil lulusan mencerminkan kemampuan minimal yang harus dikuasai mahasiswa setelah lulus yang merujuk pada empat aspek kebutuhan (1) sikap (attitude), (2) bidang kemampuan kerja, (3) pengetahuan, dan (4) manajerial dan tanggung jawab. Keempat kemampuan tersebut kemudian dijabarkan ke dalam sebuah capaian pembelajaran pada setiap mata kuliah di program studi. Sehingga nantinya, semua perencanaan pembelajaran atau Rencana Pelaksanaan Semester (RPS) harus didasarkan pada capaian pembelajaran yang sesuai dengan kebutuhan profil lulusan (Effiyanti, 2018).

\section{Metode Penelitian}

Jenis penelitian ini adalah penelitian pengembangan (research and development). Penelitian pengembangan ini merujuk pada model 4-D (four-D model) yang terdiri dari empat tahapan pendefinisian (define), tahap perancangan (design), tahap pengembangan (develop), dan tahap penyebaran (desseminate) (Thiagarajan, 1974). Penelitian ini hanya sampai pada tahap pengembangan. Meskipun hanya sampai pada tahap pengembangan, perangkat pembelajaran ini sudah mencakup prinsip penelitian pengembangan. Menurut Mulyatiningsih (2016), inti dari penelitian pengembangan adalah adanya validasi dan revisi terhadap perangkat pembelajaran yang dikembangkan. Jenis data yang diperoleh dalam analisis buku ini adalah data kualitatif dan kuantitatif. Data kualitatif adalah komentar,

Copyright (C) 2020 JEC | ISSN 2715-3029 (p) 2685-4880 (e) Volume 2, Nomor 1, 2020 
saran atau kritik dari validator. Sedangkan data kuantitatif berupa angka yang diperoleh berdasarkan lembar validasi menggunakan skala likert (range 1 - 4). Dimana kriterianya adalah 4 = sangat baik, 3 = baik, 2 = kurang baik, 1 = Tidak baik. Instrumen pengumpulan data yang digunakan dalam penelitian ini adalah lembar validasi perangkat pembelajaran. Teknik analisis data yang digunakan untuk menganalisis data hasil validasi RPS adalah teknik perhitungan rata-rata. Menurut Arikunto (2006), kisaran kriteria validasi untuk hasil perhitungan lengkap dapat diamati pada Tabel 1.

Tabel 1. Kriteria Validitas Analisis Nilai RataRata

\begin{tabular}{ll}
\hline Rata-rata & Kriteria Validitas \\
\hline $3,26-4,00$ & $\begin{array}{l}\text { Valid dan perlu revisi (sangat layak) } \\
\text { Cukup valid dan perlu revisi (Cukup }\end{array}$ \\
$2,51-3,25$ & $\begin{array}{l}\text { layak) } \\
\text { Kurang valid, sebagian isi modul } \\
\text { direvisi (kurang layak) } \\
\text { Tidak valid dan perlu revisi total }\end{array}$ \\
$1,76-2,50$ & (tidak layak) \\
\hline
\end{tabular}

\section{Hasil Penelitian dan Pembahasan}

Hasil dari penelitian pengembangan ini adalah produk berupa RPS dan RTM yang disusun berdasarkan kurikulum KKNI pada mata kuliah kimia dasar dijurusan Teknik kimia ITM. Adapun tahapan pengembangan yang dilakukan pada penelitian ini, yaitu (1) tahap pendefinisian, pada tahap ini dilakukan observasi mengenai mata kuliah kimia dasar. Observasi yang dilakukan adalah observasi mengenai perangkat yang digunakan oleh dosen pengampu. Hasil yang diperoleh adalah perangkat yang digunakan masih belum lengkap dan masih mengacu ke kurikulum yang lama. Perangkat pembelajaran yang ada adalah kontrak perkuliahan dan GBRP (Garis Besar Rencana Pembelajaran). sedangkan perangkat pembelajaran yang lengkap meliputi kontrak kuliah, silabus mata kuliah, Rencana 4

Copyright (C) 2020 JEC | ISSN 2715-3029 (p) 2685-4880 (e) Volume 2, Nomor 1, 2020
Pembelajaran Semester (RPS), Rencana Proses pembelajaran (RPP), Rancangan Tugas Mahasiswa (RTM), Lembar Kerja Mahasiswa (LKM), dan lembar penilaian hasil belajar (Monalisa, 2016).

Tahap kedua yaitu tahap perancangan, pada tahap ini mulai dibuat perangkat pembelajaran meliputi dari Rencana Pembelajaran Semester dan Rancangan Tugas Mahasiswa. Rencana pembelajaran semester yang dibuat meliputi (a) Nama program studi, nama dan kode mata kuliah, semester, sks, nama dosen pengampu; (b) Capaian pembelajaran lulusan yang dibebankan pada mata kuliah; (c) Kemampuan akhir yang direncanakan pada tiap tahap pembelajaran untuk memenuhi capaian pembelajaran lulusan; (d) Bahan kajian yang terkait dengan kemampuan yang akan dicapai; (e) Kegiatan pembelajaran; (f) Waktu yang disediakan untuk mencapai kemampuan pada tiap tahap pembelajaran; (g) Pengalaman belajar mahasiswa yang diwujudkan dalam deskripsi tugas yang harus dikerjakan oleh mahasiswa selama satu semester; (h) Kriteria, indikator, dan bobot penilaian; dan (i) Daftar referensi yang digunakan.

Rancangan tugas mahasiswa (RTM) yang dibuat meliputi beberapa jenis tugas yang terdiri dari Tugas Rutin (TR), Critical Book Review (CBR), Journal Review (JR), Miniriset (MR), Rekayasa Ide (RI), dan Projek (PR). Penugasan yang diberikan sesuai dengan materi yang ada pada mata kuliah kimia dasar. Setiap penugasan memiliki standar penilaian masingmasing.

Tahap terakhir adalah tahap pengembangan. Tahap ini bertujuan untuk menghasilkan perangkat pembelajaran (RPS dan RTM) yang telah valid/layak untuk digunakan. Pada tahap ini hasil perancangan perangkat pembelajaran materi kimia dasar diserahkan kepada validator. Validator yang menilai yaitu 
ahli pengembangan dan ahli materi. Hasil validasi untuk RPS dapat dilihat pada Tabel 2 .

Tabel 2. Hasil Validasi Rencana Pembelajaran Semester

\begin{tabular}{|c|c|c|c|c|c|}
\hline \multirow{2}{*}{ No } & \multirow{2}{*}{$\begin{array}{c}\text { Aspek yang di } \\
\text { telaah }\end{array}$} & \multicolumn{2}{|c|}{ Nilai } & \multirow[t]{2}{*}{$\sum_{\text {Skor }}$} & \multirow{2}{*}{$\begin{array}{c}\text { Skor } \\
\text { rata- } \\
\text { rata }\end{array}$} \\
\hline & & I & II & & \\
\hline 1 & $\begin{array}{l}\text { Format RPS } \\
\text { Format RPS } \\
\text { sesuai KKNI, } \\
\text { Komponennya } \\
\text { terdiri atas : } \\
\text { 1. Identitas RPS } \\
\text { 2. Capaian } \\
\text { Pembelajaran } \\
\text { 3. Deskripsi } \\
\text { singkat mata } \\
\text { kuliah } \\
\text { 4. Bahan Kajian } \\
\text { 5. Matriks mata } \\
\text { kuliah } \\
\text { 6. } \\
\text { sumber/alat/bah } \\
\text { an pembelajaran }\end{array}$ & 4 & 3 & 7 & 3,5 \\
\hline 2 & $\begin{array}{l}\text { Identitas RPS } \\
\text { Identitas RPS } \\
\text { lengkap berisi } \\
\text { nama mata kuliah, } \\
\text { kode mata kuliah, } \\
\text { rumpun mata } \\
\text { kuliah, bobot } \\
\text { mata kuliah dan } \\
\text { dosen pengampu } \\
\text { mata kuliah. }\end{array}$ & 4 & 4 & 8 & 4 \\
\hline 3 & $\begin{array}{l}\text { Capaian } \\
\text { Pembelajaran } \\
\text { CPL pada KKNI } \\
\text { terutama yang } \\
\text { berkaitan dengan } \\
\text { unsur } \\
\text { ketrampilan } \\
\text { khusus } \\
\text { (kemampuan } \\
\text { kerja) dan } \\
\text { penguasaan } \\
\text { pengetahuan, } \\
\text { sedangkan yang } \\
\text { mencakup sikap }\end{array}$ & 4 & 4 & 8 & 4 \\
\hline
\end{tabular}

\begin{tabular}{|c|c|c|c|c|c|}
\hline \multirow[t]{2}{*}{ No } & \multirow{2}{*}{$\begin{array}{l}\text { Aspek yang di } \\
\text { telaah }\end{array}$} & \multicolumn{2}{|c|}{ Nilai } & \multirow[t]{2}{*}{$\sum_{\text {Skor }}$} & \multirow{2}{*}{$\begin{array}{l}\text { Skor } \\
\text { rata- } \\
\text { rata }\end{array}$} \\
\hline & & I & II & & \\
\hline & $\begin{array}{l}\text { dan keterampilan } \\
\text { umum dapat } \\
\text { mengacu pada } \\
\text { rumusan yang } \\
\text { telah ditetapkan } \\
\text { dalam SN-Dikti }\end{array}$ & & & & \\
\hline 4 & $\begin{array}{l}\text { Deskripsi singkat } \\
\text { mata kuliah } \\
\text { Uraian singkat me } \\
\text { ngenai mata } \\
\text { kuliah tepat dan } \\
\text { sistematis }\end{array}$ & 4 & 4 & 8 & 4 \\
\hline 5 & $\begin{array}{l}\text { Bahan kajian } \\
\text { Tepat dan } \\
\text { sistematis }\end{array}$ & 4 & 4 & 8 & 4 \\
\hline 6 & $\begin{array}{l}\text { Kegiatan } \\
\text { pembelajaran } \\
\text { sesuai } \\
\text { dengan capaian } \\
\text { pembelajaran }\end{array}$ & 3 & 3 & 6 & 3 \\
\hline 7 & $\begin{array}{l}\text { Pokok bahasan } \\
\text { dan sub pokok } \\
\text { bahasan jelas dan } \\
\text { sistematis }\end{array}$ & 4 & 4 & 8 & 4 \\
\hline 8 & $\begin{array}{l}\text { Indikator } \\
\text { pembelajan } \\
\text { menggambarkan } \\
\text { rincian capaian } \\
\text { pembelajran } \\
\text { sudah jelas dan } \\
\text { tepat }\end{array}$ & 3 & 4 & 7 & 3,5 \\
\hline 9 & $\begin{array}{l}\text { Model } \\
\text { Pembelajaran } \\
\text { sesuai dengan } \\
\text { materi dan } \\
\text { pencapaian } \\
\text { indicator } \\
\text { pembelajaran }\end{array}$ & 4 & 3 & 7 & 3,5 \\
\hline 10 & $\begin{array}{l}\text { Waktu } \\
\text { Alokasi waktu } \\
\text { yang } \\
\text { digunakan sesuai }\end{array}$ & 4 & 4 & 8 & 4 \\
\hline 11 & $\begin{array}{l}\text { Penilaian } \\
\text { Jenis tagihan } \\
\text { dan }\end{array}$ & 4 & 4 & 8 & 4 \\
\hline
\end{tabular}




\begin{tabular}{lllll}
\hline No & \multicolumn{1}{c}{$\begin{array}{c}\text { Aspek yang di } \\
\text { telaah }\end{array}$} & Nilai & $\begin{array}{c}\sum_{\text {Skor }} \\
\text { Skor }\end{array}$ & $\begin{array}{c}\text { Skor } \\
\text { rata- } \\
\text { rata }\end{array}$ \\
\cline { 2 - 5 } & I & II & & \\
\hline $\begin{array}{l}\text { bentuk } \\
\text { instrumen } \\
\text { penilaian jelas. }\end{array}$ & & & & \\
\hline 12 & & & & \\
$\begin{array}{l}\text { Alat dan Bahan } \\
\text { Ajar }\end{array}$ & 3 & 3 & 6 & 3 \\
$\quad \begin{array}{l}\text { Alat dan bahan } \\
\text { ajar } \\
\text { sesuai } \\
\text { untuk } \\
\text { mencapai }\end{array}$ & & & & \\
indicator & & & & \\
\hline Rata-rata skor penilaian & & & \\
\hline Kriteria & & & \\
\hline
\end{tabular}

Berdasarkan hasil analisis validasi kelayakan Rencana Pembelajaran Semester memperoleh nilai rata-rata 3,7 dengan kategori sangat layak. Hal ini dikarenakan pada tahap pengembangan RPS ini telah dilakukan beberapa kali perbaikkan berdasarkan saran dan kritikan yang diberikan validator.

Perangkat pembelajaran selanjutnya berupa Rancangan Tugas Mahasiswa (RTM). Hasil validasi untuk RPS dapat dilihat pada Tabel 3.

Tabel 3. Hasil Validasi Rancangan Tugas Mahasiswa

\begin{tabular}{|c|c|c|c|c|c|}
\hline \multirow[t]{2}{*}{ No } & \multirow[t]{2}{*}{$\begin{array}{l}\text { Aspek yang di } \\
\text { telaah }\end{array}$} & \multicolumn{2}{|c|}{$\begin{array}{l}\text { Penilaian } \\
\text { Validator }\end{array}$} & \multirow[t]{2}{*}{$\underset{\text { Skor }}{\sum}$} & \multirow[t]{2}{*}{$\begin{array}{l}\text { Skor } \\
\text { rata- } \\
\text { rata }\end{array}$} \\
\hline & & I & II & & \\
\hline 1 & $\begin{array}{l}\text { RTM terdiri dari } \\
\text { jenis tugas yang } \\
\text { sesuai dengan } \\
\text { Capaian } \\
\text { Pembelajaran } \\
\text { KKNI memuat } \\
\text { pengetahuan, } \\
\text { sikap dan } \\
\text { keterampilan }\end{array}$ & 4 & 4 & 8 & 4 \\
\hline
\end{tabular}

6

Copyright () 2020 JEC | ISSN 2715-3029 (p) 2685-4880 (e)

Volume 2, Nomor 1, 2020

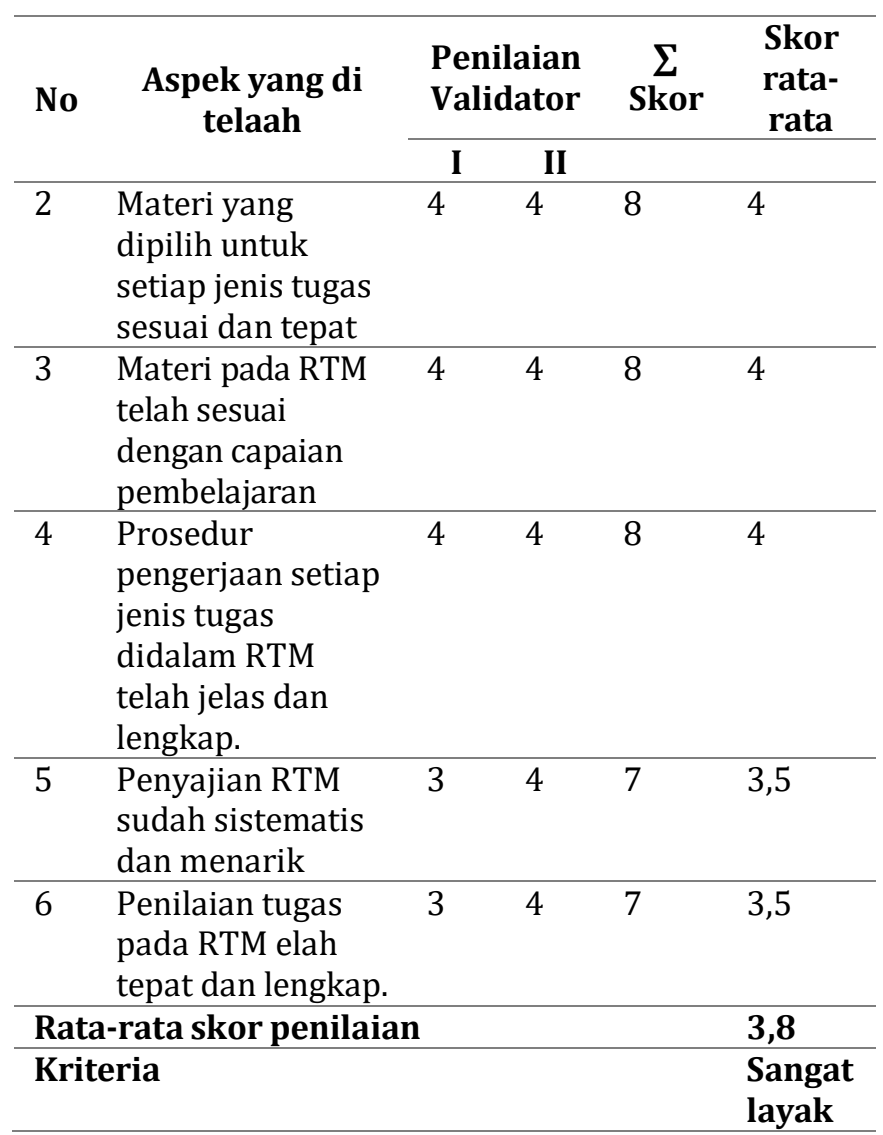

Validator satu menyarankan bahwa untuk kriteria penilaian ketepatan konsep sudah baik, untuk beberapa materi utama pada kimia dasar itu sudah termasuk dalam kebenaran konsep dan untuk indikator Rancangan Tugas Mahasiswa (RTM) tidak harus sama, tergantung deskripsi tugas. Validator dua menyatakan bahwa rancangan tugas mahasiswa sudah sesuai dengan kerangka kualifikasi nasional Indonesia. Dalam rancangan tugas mahasiswa KKNI sebaiknya terdiri dari tugas yang berbeda jenisnya, hal ini agar meningkatkan mutu mahasiswa dalam pencapaian pembelajaran dari segi pengetahuan, sikap dan keterampilan. Selain itu RTM juga telah dilengkapi dengan pengertian setiap jenis tugas, proses pengerjaan, sistematika laporan serta indikator penilaian yang disesuaikan dengan karakter jenis tugas. 
Sehingga berdasarkan penilaian untuk perangkat Rancangan Tugas Mahasiswa telah termasuk kriteria sangat layak dan dapat diimplementasikan.

\section{Simpulan dan Saran}

\section{Simpulan}

Berdasarkan hasil analisis data dan pembahasan terhadap proses dan hasil pengembangan perangkat pembelajaran berbasis Kerangka Kualifikasi Nasional Indonesia maka dapat diambil simpulan sebagai berikut:

1. Pada penelitian ini telah berhasil mengembangkan perangkat pembelajaran berupa Rencana Pembelajaran Semester (RPS) dan rancangan Tugas Mahasiswa (RTM) berdasarkan kurikulum KKNI pada mata kuliah kimia dasar di jurusan Teknik kimia ITM

2. Perangkat pembelajaran yang dikembangkan dalam penelitian ini telah memenuhi kriteria validitas (validity) yang didapatkan melalui pendapat validator. Dengan keterangan rencana pembelajaran semester dan rancangan tugas mahasiswa termasuk kriteria sangat layak

\section{Saran}

Penelitian selanjutnya dapat menguji secara empiris implementasi dari perangkat pembelajaran yang telah dikembangkan, pengujian empiris sangat penting untuk mendapatkan bukti kinerja dari instrument tersebut. Kinerja instrument dapat ditinjau berdasarkan kepuasan belajar mahasiswa maupun kinerja akademik yang didapatkan mahasiswa akibat dari penggunaan perangkat pembelajaran tersebut. Selain itu, penelitian selanjutnya dapat mengembangkan perangkat pembelajaran lain seperti bahan ajar, lembar kerja mahasiswa dan instrument penilaian hasil belajar.

\section{Daftar Pustaka}

Arikunto, S. (2006). Prosedur Penelitian Suatu Pendekatan Praktek. Jakarta : Rineka Cipta.

Effiyanti, T., Pratiwi, D. E., \& Dalimunthe, M. B. Pengembangan Perangkat Pembelajaran Berorientasi Kkni Pada Mata Kuliah Ekonomi Syariah. Niagawan, 7(1), 44-49.

Iborra, M., Ramírez, E., Tejero, J., Bringué, R., Fité, C., \& Cunill, F. (2014). Revamping of teaching-learning methodologies in laboratory subjects of the Chemical Engineering undergraduate degree of the University of Barcelona for their adjustment to the Bologna process. Education for Chemical Engineers, 9(3), e43-e49.

Indonesia, P. R. (2012). Peraturan Presiden Republik Indonesia Nomor 8 Tahun 2012 Tentang Kerangka Kualifikasi Nasional Indonesia.Jakarta: Kementerian Riset, Teknologi, dan Pendidikan Tinggi.

Kemendikbud. 2014. Buku Kurikulum Pendidikan Tinggi. Jakarta: Direktorat Jendral Pendidikan Tinggi.

Kemendikbud. 2014. Panduan Penyusunan: Capaian Pembelajaran Lulusan Program Studi. Jakarta: Direktorat Jendral Pendidikan Tinggi.

Monalisa, L. A., \& Trapsilasiwi, D. (2016). Pengembangan Perangkat Pembelajaran Mata Kuliah Teori Bilangan Program Studi Pendidikan Matematika Berdasarkan Kurikulum Kerangka Kualifikasi Nasional Indonesia (KKNI).

Mulyatiningsih, E. (2016). Pengembangan Model Pembelajaran. Diakses dari http://staff. uny. ac. $\quad$ id/sites/default/files/pengabdian/draendang-mulyatiningsih- 
mpd/7cpengembangan-model-pembelajaran. pdf. pada September.

Nurdin, S. (2018). Pengembangan kurikulum dan rencana pembelajaran semester (RPS) berbasis KKNI di perguruan tinggi. AlFikrah: Jurnal Manajemen Pendidikan,5(1), 21-30.

Prausnitz, J. M. (2011). Chemical engineering and the postmodern world.Chemical Engineering Research and Design,79(7), 777-788.

Solikha, D. F. (2015). Bahan Ajar Asam-Basa Menggunakan Konteks Bahan Pengawet Makanan untuk Mengembangkan Literasi Sains SMK Jurusan Teknologi Pengolahan Hasil Pertanian (TPHP).Jurnal Penelitian Pendidikan, 15(2). 